\title{
Occurrence of entomopathogenic fungi in populations of Metopolophium dirhodum (Walker) aphids feeding on primary and secondary host plants
}

\author{
Występowanie grzybów entomopatogenicznych w populacjach mszycy \\ Metopolophium dirhodum (Walker) żerującej na pierwotnych \\ i wtórnych roślinach żywicielskich
}

\author{
Cezary Tkaczuk, Robert Krzyżanowski*
}

\section{Summary}

No fungal infections were found among the founders of the Metopolophium dirhodum (Walker) on saltspray rose (Rosa rugosa) in spring whereas in the fundatrigeniae populations, three species of entomopathogenic fungi were recorded: Conidiobolus obscurus (Hall et Dunn), Entomophthora planchoniana Cornu and Pandora neoaphidis (Remaudière et Hennebert) Humber. Autumn observations revealed that the mycoses occurring in the populations of $M$. dirhodum were caused by the same three entomophthoralean fungal species (Entomophthoromycota). These three species of entomopathogenic fungi were also recorded on $M$. dirhodum individuals feeding on cereals. It was found that aphids, as a result of direct contact with soil substrate taken in spring from primary hosts, were infected by two species of fungi, i.e. C. obscurus and P. neoaphidis, which indicates that the soil may be one of the sources of infectious material of these fungal species in early spring period.

Key words: Metopolophium dirhodum; Rosa rugosa; entomophthoralean fungi

\section{Streszczenie}

Wiosną na zielonych pędach róży pomarszczonej nie stwierdzono infekcji grzybowych wśród założycielek rodu mszycy różanotrawowej Metopolophium dirhodum (Walker), natomiast w populacjach fundatrigeniae odnotowano obecność trzech gatunków pasożytniczych grzybów: Conidiobolus obscurus (Hall \& Dunn), Entomophthora planchoniana Cornu i Pandora neoaphidis (Remaudière \& Hennebert) Humber. Jesienią w populacjach $M$. dirhodum na róży pomarszczonej spotykano infekcje spowodowane przez te same trzy gatunki grzybów owadomorkowych (Entomophthoromycota). Wymienione trzy gatunki grzybów owadobójczych odnotowano również na osobnikach $M$. dirhodum żerujących na zbożach. Stwierdzono, że mszyce w wyniku bezpośredniego kontaktu z podłożem glebowym pobranym wiosną spod żywicieli pierwotnych, ulegały infekcjom spowodowanym przez dwa gatunki grzybów, tj. C. obscurus i P. neoaphidis, co wskazuje na to, że gleba może być jednym ze źródeł materiału infekcyjnego tych gatunków w okresie wczesnowiosennym.

Słowa kluczowe: Metopolophium dirhodum; Rosa rugosa; grzyby entomopatogeniczne

\footnotetext{
Uniwersytet Przyrodniczo-Humanistyczny w Siedlcach

Wydział Przyrodniczy

Prusa 14, 08-110 Siedlce

*corresponding author: robert.krzyzanowski@uph.edu.pl
} 


\section{Wstęp / Introduction}

Problematyka ochrony zbóż przed chorobami, szkodnikami i chwastami obejmuje także mszyce zbożowe, które podczas gradacji wpływają pośrednio i bezpośrednio na znaczny spadek plonowania roślin zbożowych. Straty plonów powodowane przez szkodniki w Polsce wynoszą średnio około 6-7\% (Goszczyński 1993). Podczas żerowania na roślinach żywicielskich mszyce zbożowe wysysają wraz z sokiem komórkowym znaczne ilości podstawowych metabolitów roślinnych oraz powodują mechaniczne uszkodzenie tkanek (Leszczyński 1985; Leszczyński i wsp. 1986; Urbańska i Niraz 1990; Burd 2002; Gadalińska-Krzyżanowska 2011). Do komórek żywiciela wraz ze śliną owada wprowadzane są enzymy oraz inne związki organiczne, powodujące wzrost aktywności procesów katabolicznych oraz obniżenie poziomu biosyntezy w jego tkankach. W miejscach nakłuwania zaatakowanych roślin pojawiają się ubytki tkanek lub żółte plamki, z których po pewnym czasie powstają nekrozy. Podczas żerowania owadów na roślinach następuje degradacja błon komórkowych oraz dezintegracja chloroplastów, powodująca spadek aktywności fotosyntezy (Smith i wsp. 2005; Zwiener i wsp. 2005).

Szkodliwość pośrednia mszyc zbożowych wynika z przenoszenia przez nie wirusów oraz wydzielania rosy miodowej, na której dobrze rozwijają się ciemne naloty grzybów sadzakowych z rodzaju Capnodium, utrudniając procesy fotosyntezy i transpiracji (Chomnunti i wsp. 2014). Ponadto rosa miodowa blokuje aparaty szparkowe znacznie ograniczając wymianę gazową i przyspieszając procesy starzenia zaatakowanych roślin. Przykładowo zasiedlanie pszenicy przez mszyce Sitobion avenae (F.) i Metopolophium dirhodum (Walk.) w Wielkiej Brytanii, powodowało żółknięcie liści około tygodnia wcześniej i straty plonów rzędu 1,5 t/ha (Wratten i Readhead 1976). Szkodliwość pośrednia mszyc jest związana również z przenoszeniem wirusów, a niektóre gatunki, np. mszyca brzoskwiniowa Myzus persicae (Sulz.) mogą przenosić około stu różnych wirusów (Cichocka 1980). Wśród mszyc zbożowych, mszyca czeremchowo-zbożowa, Rhopalosiphum padi (L.) jest wektorem wirusa żółtej karłowatości jęczmienia (BYDV), powodującego obniżenie plonów zbóż od 5 do 10\% (Ruszkowska 2002).

Wiele naturalnych wrogów, takich jak drapieżniki, pasożyty i patogeny może ograniczać populacje mszyc. Ważnym regulatorem liczebności mszyc w biocenozach w Polsce są pasożytnicze grzyby entomopatogeniczne, które potrafią obniżać ich populację do poziomu nieszkodliwego. Epizoocje mszyc wywołane przez grzyby entomopatogeniczne są często obserwowane w populacjach tych szkodników żerujących na zbożach, gdzie ich śmiertelność spowodowana przez te patogeny w niektórych okresach przekracza $60 \%$ (Feng i wsp. 1991; Steenberg i Eilenberg 1995).

Niższe grzybowe patogeny mszyc to głównie owadomorkowce (Entomophthoromycota), zaliczane do klasy sprzężniaków (Zygomycetes) (Bałazy i wsp. 1990; Steenberg i Eilenberg 1995; Barta i Cagaň 2006; Ben Fekih i wsp. 2015). Mniej liczną grupę grzybowych patogenów mszyc stanowią gatunki reprezentujące grupę grzybów wyższych, będące niedoskonałymi (konidialnymi) stadiami workowców (Hypocreales: Ascomycota) i wywodzące się głównie z rodzajów Lecanicillium czy Beauveria (Bałazy i wsp. 1990).

O ile stosunkowo dużo uwagi poświęcono badaniom nad mikozami mszyc występujących na zbożach, o tyle ich rola $\mathrm{w}$ ograniczaniu populacji dwudomnych gatunków tych owadów, rozwijających się na żywicielach pierwotnych jest stosunkowo mało poznana. Dotychczasowe badania dotyczące składu gatunkowego grzybów entomopatogenicznych pozwoliły na wyizolowanie z gynopare i samców $R$. padi jesienią następujących gatunków owadomorków: Entomophthora planchoniana, Pandora neoaphidis, Zoophthora phalloides (Humber \& Ben Ze'ev), Conidiobolus obscurus oraz Neozygites fresenii (Nowakowski). Dominującymi gatunkami były $N$. fresenii, C. obscurus i E. planchoniana. Z. phalloides identyfikowany był raczej sporadycznie. Wiosną w populacjach założycielek rodu nie stwierdzano chorób grzybowych, natomiast na fundatrigeniae odnotowano obecność nielicznych infekcji wywołanych przez C. obscurus, P. neoaphidis i N. fresenii (Bode 1980; Dedryver i wsp. 1983; Nielsen i Steenberg 2004). Z kolei przypadki mikoz $M$. dirhodum na pierwotnym i wtórnym żywicielu są mało poznane.

Celem podjętych badań było poznanie składu gatunkowego grzybów owadobójczych infekujących mszycę różano-trawową i określenie ich roli w ograniczaniu populacji tych owadów, zarówno w odniesieniu do form żerujących na żywicielach pierwotnych, jak i wtórnych.

\section{Materiały i metody / Materials and methods}

W celu stwierdzenia infekcji mszyc i określenia stopnia ich spasożytowania przez grzyby owadobójcze prowadzono w latach 2008-2009 obserwacje na krzewach róży pomarszczonej Rosa rugosa Thunb. (żywiciel pierwotny) rosnących w parku „Aleksandria” i na skwerach miejskich w Siedlcach. W okresie wczesnej wiosny (marzec-maj) i późnej jesieni (wrzesień-październik) w odstępach 7-dniowych pobierano losowo po 20 ulistnionych pędów. Na żywicielach wtórnych (pszenica i pszenżyto) badania prowadzone były na plantacjach polowych w okolicach Siedlec i koncentrowały się głównie na poznaniu składu gatunkowego grzybów, ale przy silnych epizoocjach dokonywano również oceny stopnia porażenia mszyc przez grzyby. Próby pobierano w odstępach dwutygodniowych, kontrolując 25 losowo wybranych roślin w łanie. Materiał roślinny z mszycami przenoszono do laboratorium, gdzie występujące na zainfekowanych osobnikach gatunki grzybów były opisywane na podstawie diagnostyki morfologicznej zgod- 
nie z metodami podanymi przez Humbera $(1989,2012)$, Bałazego (1993) oraz Kellera (2007).

Obserwowanym stanowiskiem w latach 2008-2009 była monokultura zboża. Terminy siewu pszenicy ozimej i pszenżyta ozimego przypadały od 20 do 30 września i były optymalne dla tego rejonu kraju. Nasiona przeznaczone do siewu odznaczały się dobrym wyrównaniem i masą 1000 ziaren, czystością około 98\%, zdolnością kiełkowania około $90 \%$ i wilgotnością poniżej 15\%. Ziarno siewne zostało zaprawione i wysiane na głębokość 3-4 cm, a szerokość międzyrzędzi wynosiła $10-12 \mathrm{~cm}$. Bezpośrednio po siewie zastosowano opryskiwanie preparatem Dicuran $80 \mathrm{WP}$ w ilości $2 \mathrm{~kg} / \mathrm{ha}$, zwalczającym miotłę zbożową i chwasty dwuliścienne. Dawka azotu dla badanych pszenic wynosiła 80-160 kg N/ha, natomiast dla pszenżyt $90-110 \mathrm{~kg} \mathrm{~N} / \mathrm{ha}$.

Liczebność populacji mszyc zbożowych na badanych odmianach pszenicy ozimej i pszenżyta ozimego określano w warunkach wolnego nalotu według zaleceń Wratten'a i wsp. (1979) oraz Lykouressis'a (1984). Obserwacje rozpoczęto od momentu pojawienia się migrujących mszyc na badanych odmianach zbóż ozimych i kontrolowano do stadium późnej dojrzałości woskowej. Liczebność populacji każdorazowo szacowano na 25 roślinach, po przekątnej, w trzech powtórzeniach.

W celu oceny obecności form infekcyjnych owadomorków na powierzchni gleby, na przełomie marca i kwietnia 2008 r. pobrano próby glebowe spod krzewów róży pomarszczonej. Próbki pobierano za pomocą łopatki z wierzchniej warstwy gleby (do $5 \mathrm{~cm}$ ), tak aby nie naruszyć struktury gleby. W laboratorium, glebą z każdego stanowiska napełniano po 10 szalek Petriego i po powierzchniowym zwilżeniu wykładano po 10 sztuk bezskrzydłych osobników M. dirhodum, pochodzących z hodowli laboratoryjnej. Szalki z glebą i mszycami inkubowano w temperaturze $18-20^{\circ} \mathrm{C}$, a następnie przez pięć kolejnych dni sprawdzano śmiertelność mszyc i określano czynniki ich śmiertelności. Martwe osobniki z objawami infekcji grzybowej przenoszono na szkiełka podstawowe i umieszczano w szalce Petriego wyłożonej wilgotnym papierem filtracyjnym. Martwe osobniki mszyc niewykazujące objawów infekcji sterylizowano powierzchniowo $\mathrm{w} 1 \%$ podchlorynie sodu, a następnie przenoszono na szkiełka mikroskopowe i umieszczano w mokrych kamerach. Odrzucane aktywnie na szkiełko zarodniki konidialne grzybów owadomorkowych utrwalano w laktofenolu $\mathrm{z}$ dodatkiem acetoorceiny i sporządzano preparaty mikroskopowe, na podstawie których oznaczano je do gatunku.

\section{Wyniki i dyskusja / Results and discussion}

Wyniki przeprowadzonych wcześniej obserwacji przez Krzyżanowskiego (2017), na kontrolowanych pędach róży pomarszczonej, bez epizoocji grzybowych, wykazały że dynamika liczebności mszycy różano-trawowej, $M$. dirhodum na żywicielu pierwotnym w latach 2005-2009 miała charakter krzywych jednowierzchołkowych. W latach 2005-2007 pierwsze założycielki rodu (fundatrices) występowały na żywicielu pierwotnym w drugiej dekadzie kwietnia. Maksymalną liczebność populacji mszycy różano-trawowej zaobserwowano w pierwszej dekadzie maja, po czym odnotowano spadek liczebności $M$. dirhodum na róży pomarszczonej, będący rezultatem wiosennych migracji z żywiciela pierwotnego na zboża. W kolejnych dwóch latach badań (2008-2009) autorzy na kontrolowanych pędach stwierdzili obecność fundatrices już w trzeciej dekadzie marca, a maksymalną liczebność populacji mszycy różano-trawowej w drugiej dekadzie maja i pierwszej dekadzie czerwca. Po tym okresie nastąpił gwałtowny spadek liczebności badanej mszycy na róży pomarszczonej.

Krzyżanowski (2017) wskazał również, że jesienne reemigracje $M$. dirhodum na żywiciela pierwotnego we wszystkich badanych sezonach (2005-2009), rozpoczynały się w pierwszej dekadzie września, kiedy na $R$. rugosa zaobserwowano obecność pierwszych morf płciowych. Najwięcej morf płciowych mszycy różano-trawowej stwierdzono w drugiej dekadzie września.

Mszyce, jako owady o kłująco-ssącym narządzie gębowym preferują najmłodsze, szybko rosnące części roślin (Cichocka 1980; Dąbrowski 1988). Jednakże w wyniku zwiększenia udziału w profilu roślinnych lotnych związków, takich jak salicylan metylu, opuszczają dotychczasowego żywiciela pierwotnego (Krzyżanowski i Leszczyński 2009). Podczas późniejszych faz rozwojowych roślin żywicielskich, na ogół wzrasta śmiertelność mszyc oraz spada ich płodność i tempo wzrostu. Zależność tą obserwowano dla mszyc zbożowych: S. avenae, M. dirhodum i R. padi (Leather 1982; Howard i Dixon 1992; Zhou i Carter 1992).

Badania Gadalińskiej-Krzyżanowskiej (2011) wykazały, że w trakcie badanych sezonów wegetacyjnych $M$. dirhodum najwcześniej pojawiała się na żywicielu pierwotnym w roku 2007, a najpóźniej w roku 2006. Skutkowało to w roku 2007 znacznie szybszym wzrostem populacji pokoleń pierwodomnych, wcześniejszym o dwa tygodnie wystąpieniem maksimum liczebności oraz większą liczebnością szkodników na żywicielach pierwotnych. Znalazło to także odzwierciedlenie $\mathrm{w}$ wyższych wartościach kumulatywnego indeksu mszycowego (KIM) w roku 2007, na wszystkich badanych przez autorkę roślinach zbożowych. Poziom populacji szkodnika na żywicielu pierwotnym, w znaczącym stopniu decydował o jego występowaniu na żywicielu wtórnym. Spośród badanych pszenic i pszenżyt ozimych odmiana Oliwin oraz ród RAH 366 były odpowiednio najliczniej zasiedlane przez mszyce zbożowe.

Wiosną 2008 roku na zielonych pędach róży pomarszczonej nie stwierdzono infekcji grzybowych wśród założycielek rodu mszycy różano-trawowej, natomiast w populacjach fundatrigeniae, stwierdzono obecność trzech ga- 
tunków grzybów owadobójczych z grupy owadomorków: E. planchoniana, P. neoaphidis i C. obscurus. Zainfekowały one łącznie 14,6\% badanych osobników. Dominował gatunek E. planchoniana, który zainfekował średnio 9,2\% osobników (tab. 1). Zaobserwowano, że infekcje nasilały się kilka dni po opadach deszczu. Najwięcej mszyc zainfekowanych przez grzyby zaobserwowano na $R$. rugosa w pierwszej dekadzie czerwca $(18,6 \%)$. Warto odnotować także fakt, że po wiosennych migracjach $M$. dirhodum na żywicieli wtórnych, na pędach róży pomarszczonej obserwowano martwe (zmumifikowane osobniki), wypełnione zarodnikami przetrwalnikowymi E. planchoniana, co wskazuje na możliwość przetrwania inokulum grzybowego na żywicielu pierwotnym do jesieni, a więc reemigracji na żywiciela pierwotnego celem złożenia jaj.

W drugim roku obserwacji wiosną (2009), w populacjach fundatrigeniae $M$. dirhodum rozwijających się na róży, odnotowano obecność dwóch gatunków pasożytniczych grzybów: E. planchoniana i P. neoaphidis. Owadomorki w badanym okresie zainfekowały łącznie 15,4\% obserwowanych osobników $M$. dirhodum, a dominował gatunek E. planchoniana, który spowodował śmiertelność $10,2 \%$ mszyc. Jesienią tego samego roku w pokoleniach $M$. dirhodum rozwijających się na róży pomarszczonej, stwierdzono infekcje spowodowane przez grzyby $C$. obscurus, E. planchoniana i P. neoaphidis, które zainfekowały średnio, odpowiednio 1,4; 5,3 i 2,8\% badanych osobników (tab. 1).

Wyniki przeprowadzonych badań nad infekcjami mszycy różano-trawowej w okresie ich żerowania na żywicielu pierwotnym pokrywają się z wynikami badań prowadzonych w innych krajach. Barta i wsp. (2003) badając w Austrii występowanie Entomophthorales w populacjach mszyc w czerwcu i październiku wykazali obecność czterech gatunków grzybów entomopatogenicznych na różnych gatunkach mszyc żyjących na roślinach zielnych lub drzewach: Erynia neoaphidis (Remaudiere \& Hennebert), Conidiobulus obscurus, Entomophthora planchoniana i Neozygites fresenii. Na mszycy $M$. dirhodum występowały tylko pierwsze trzy gatunki grzybów. Podobnie Remaudière i wsp. (1981) wykazali we Francji, że mszyce $M$. dirhodum były infeko- wane przez C. obscurus, E. planchoniana i P. neoaphidis. Jednakże, jak wskazuje Barta (2009) prowadząc obserwacje epizoocji grzybowych w latach 2007-2008 wykazał, że podczas żerowania mszycy $M$. dirhodum na Rosa canina L. mszyca infekowana była przez dwa gatunki $P$. neoaphidis i E. planchoniana. Podczas gdy, w momencie obserwacji infekcji grzybowych $M$. dirhodum na Rosa $\times$ hybrida autor wykazał obecność tylko jednego gatunku, a mianowicie E. planchoniana. Według Barty i Cagaňa (2006) P. neoaphidis, to główny patogen grzybowy mszyc. Martwe mszyce zainfekowane przez ten gatunek owadomorka spotykano od początku kwietnia do połowy listopada w 60 miejscowościach na Słowacji. Patogen ten infekował wiele gatunków mszyc, w tym niektóre ważne gospodarczo gatunki szkodników, takie jak: R. padi (L.), R. maidis (Fitch), M. dirhodum Walk., S. avenae (F.), Diuraphis noxia (Mordv.) i M. persicae. Podobnie Štalmachová i Cagán̆ (2000), Cagán̆ i Barta (2001), Barta i Cagán̆ (2002) wskazują, że P. neoaphidis odrywa ważną rolę w naturalnej regulacji populacji mszyc na Słowacji.

W badanej agrocenozie, w latach 2008-2009, stwierdzono występowanie trzech gatunków mszyc zbożowych: mszycy różano-trawowej ( $M$. dirhodum), mszycy czeremchowo-zbożowej ( $R$. padi) oraz mszycy zbożowej (S. avenae). Analizując dane dotyczące procentowego udziału trzech gatunków mszyc w łącznej liczebności populacji mszyc zbożowych występujących na wtórnych roślinach żywicielskich, stwierdzono że procentowy udział $M$. dirhodum w populacji mszyc zbożowych był najniższy i wynosił około $10 \%$ na pszenicy i $13 \%$ na pszenżycie.

W latach 2008-2009 na osobnikach mszycy różanotrawowej żerujących na żywicielach wtórnych (zbożach) odnotowano obecność jedynie trzech gatunków grzybów owadobójczych. Były to: E. planchoniana, P. neoaphidis i C. obscurus, należące do owadomorkowców (Entomophthoromycota) (tab. 2). Grzyby E. planchoniana i P. neoaphidis należały do dominantów i występowały corocznie w populacjach $M$. dirhodum na zbożach. Owadomorki, a zwłaszcza $P$. neoaphidis i E. planchoniana, infekowały najczęściej kilka dni po intensywnych opadach i na początku czerwca na pojedynczych roślinach stwierdzono nierzadko $40-60 \%$ osobników zainfekowanych przez grzyby owa-

Tabela 1. Średnie wartości mykoz mszyc Metopolophium dirhodum na róży pomarszczonej (Rosa rugosa) w latach 2008-2009 Table 1. Mean value of mycoses of Metopolophium dirhodum on saltspray rose (Rosa rugosa) in the years 2008-2009

\begin{tabular}{c|c|c|c|c|c}
\hline \multirow{2}{*}{$\begin{array}{c}\text { Czas obserwacji (rok) } \\
\text { Observation time (year) }\end{array}$} & \multirow{2}{*}{$\begin{array}{c}\text { Pora roku } \\
\text { Season }\end{array}$} & \multicolumn{4}{|c}{$\begin{array}{c}\text { Procent osobników zainfekowanych } \\
\text { Percent of infected individuals }\end{array}$} \\
\cline { 3 - 6 } & $\begin{array}{c}\text { Pandora } \\
\text { neoaphidis }\end{array}$ & $\begin{array}{c}\text { Conidiobolus } \\
\text { obscurus }\end{array}$ & $\begin{array}{c}\text { Entomophthora } \\
\text { planchoniana }\end{array}$ & $\begin{array}{c}\text { grzyby łącznie } \\
\text { total }\end{array}$ \\
\hline \multirow{2}{*}{2008} & wiosna - spring & 3,8 & 1,6 & 9,2 & 14,6 \\
\cline { 2 - 6 } & jesień - autumn & 1,1 & 0 & 2,3 & 3,4 \\
\hline \multirow{2}{*}{2009} & wiosna - spring & 5,2 & 0 & 10,2 & 15,4 \\
\cline { 2 - 6 } & jesień - autumn & 2,8 & 1,4 & 5,3 & 9,5 \\
\hline
\end{tabular}


Tabela 2. Gatunki grzybów powodujące mykozy mszyc Metopolophium dirhodum na zbożach w latach 2008-2009

Table 2. Species of entomopathogenic fungi causing mycoses of Metopolophium dirhodum on cereals in the years 2008-2009

\begin{tabular}{c|c|c|c}
\hline \multirow{2}{*}{$\begin{array}{c}\text { Czas } \\
\text { obserwacji } \\
\text { (rok) }\end{array}$} & \multicolumn{3}{|c}{$\begin{array}{c}\text { Gatunki grzybów owadobójczych } \\
\text { Species of entomopathogenic fungi }\end{array}$} \\
\cline { 2 - 4 } $\begin{array}{c}\text { Observation } \\
\text { time } \\
\text { (year) }\end{array}$ & $\begin{array}{c}\text { Conidiobolus } \\
\text { obscurus }\end{array}$ & $\begin{array}{c}\text { Entomophthora } \\
\text { planchoniana }\end{array}$ & $\begin{array}{c}\text { Pandora } \\
\text { neoaphidis }\end{array}$ \\
\hline 2008 & + & + & + \\
\hline 2009 & + & + & + \\
\hline
\end{tabular}

dobójcze. Przeprowadzone obserwacje ściśle korespondują z badaniami przeprowadzonymi w Danii, podczas których udokumentowano na mszycy różano-trawowej obecność trzech gatunków grzybów owadobójczych: P. neoaphidis, E. planchoniana i C. obscurus (Nielsen i wsp. 2001). Chen i Feng (2004) wykazali, że wśród grzybów zakażających mszyce zbożowe w Chinach najczęściej występują: P. neoaphidis, E. planchoniana, N. fresenii i Zoophthora spp. Ponadto gatunki z rodzaju Conidiobolus spp. występują również dość często (Humber 1989; Feng i wsp. 1990, 1991; Hatting i wsp. 1999; Li 2000).

Wyniki uzyskane z tych badań są częściowo zgodne z wcześniejszymi obserwacjami prowadzonymi przez Feng i wsp. (1990), którzy w trakcie czteroletnich badań na pszenicy, jęczmieniu i kukurydzy stwierdzili obecność aż 10 gatunków grzybów patogenicznych, w tym ośmiu należących do Entomophthoromycota. Owadomorki były reprezentowane przez gatunki: P. neoaphidis, C. obscurus, C. coronatus, C. thromboides, E. chromophidis Burger \& Swain, N. fresenii, Zoophthora radicans (Brefeld) Batko i Z. occidentalis (Thakster) Batko, natomiast spośród anamorf workowców odnotowano na mszycach obecność tylko dwóch gatunków Beauveria bassiana (Balsamo) Vuillemin i Verticillium lecanii (Zimmermann) Viégas. Grzyb Pandora neoaphidis był najczęściej występującym corocznie gatunkiem w populacji $M$. dirhodum i $D$. noxia, a także często zakażał innych gospodarzy.

W przeprowadzonym eksperymencie laboratoryjnym stwierdzono, że osobniki mszycy różano-trawowej w wyniku bezpośredniego kontaktu $\mathrm{z}$ podłożem glebowym pobranym na przełomie marca i kwietnia spod żywicieli pierwotnych, ulegały infekcjom spowodowanym przez C. obscurus, który poraził $8,3 \%$ poddanych testom osobników oraz grzyba $P$. neoaphidis który infekował 3,7\% osobników (rys. 1). Wskazuje to, że gleba może być jednym ze źródeł materiału infekcyjnego tego gatunku w okresie wczesnowiosennym. Baverstock i wsp. (2005) wykazali, że grzyby z rodziny owadomorków mogą przetrwać okres zimy w środowisku glebowym, w postaci ciał strzępkowych wewnątrz martwych zakażonych osobników mszyc, bądź

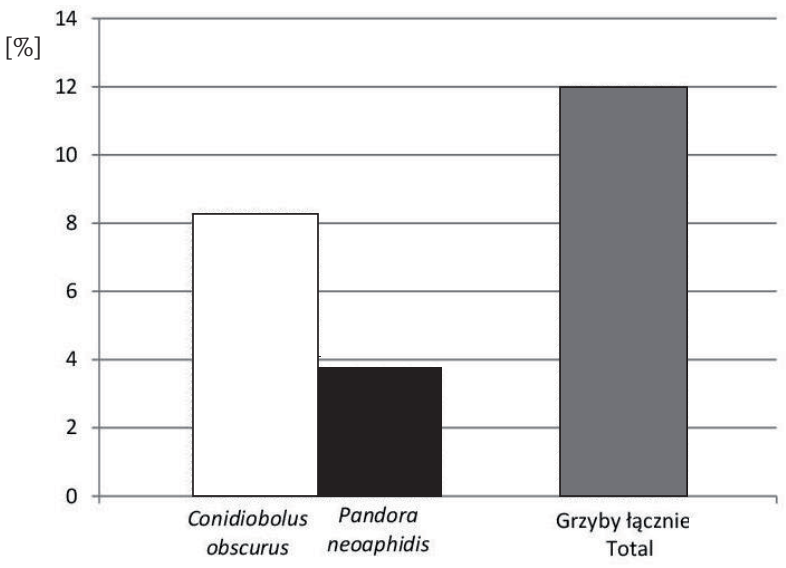

Rys. 1. Występowanie Entomophthorales infekujących Metopolophium dirhodum przez próbki gleby

Fig. 1. Occurrence of Entomophthorales infecting aphids by baiting soil samples with Metopolophium dirhodum

w formie zarodników przetrwalnikowych lub otoczonych grubymi ścianami zarodników konidialnych tzw. loricoconidiów (np. P. neoaphidis) stanowiąc źródło materiału infekcyjnego. Nielsen i wsp. (2003) udowodnili, że aktywne inokulum grzybów $C$. obscurus i $P$. neoaphidis było obecne wczesną wiosną $\mathrm{w}$ glebie uprawnej, jak i pochodzącej ze środowisk seminaturalnych, co wskazuje na możliwość jego przetrwania w glebie przez długi okres zimy, a jego źródłem były głównie zainfekowane grzybami osobniki mszyc występujące na organach roślin znajdujących się nad powierzchnią gleby. Również Latteur (1977) udokumentował obecność aktywnego inokulum $P$. neoaphidis i C. obscurus w glebie bezpośrednio po epizoocji spowodowanej przez te gatunki grzybów w populacjach mszyc, podczas gdy Corremans-Pelseneer i wsp. (1983) doszli do podobnych wniosków w przypadku grzybów C. coronatus i Conidiobolus sp.

W wyniku kontaktu z glebą nie dochodziło do infekcji spowodowanych przez grzyba E. planchoniana, co może wskazywać, że gatunek ten preferował inną strategię zimowania.

\section{Wnioski / Conclusions}

1. W trakcie prowadzonych wiosną na róży pomarszczonej obserwacji nie stwierdzono infekcji grzybowych wśród założycielek rodu mszycy różano-trawowej, natomiast w kolejnych partenogenetycznych pokoleniach fundatrigeniae odnotowano obecność trzech gatunków pasożytniczych grzybów: C. obscurus, E. planchoniana i P. neoaphidis. Najwięcej osobników M. dirhodum infekował grzyb E. planchoniana. 
2. Jesienią w populacjach $M$. dirhodum żerujących na żywicielu pierwotnym róży pomarszczonej spotykano infekcje spowodowane przez te same trzy gatunki grzybów owadomorkowych.

3. W latach 2008-2009 na osobnikach mszycy różano-trawowej żerujących na żywicielach wtórnych (zbożach), odnotowano obecność trzech gatunków grzybów należących do owadomorkowców (Entomophthoromycota). Były to: E. planchoniana, P. neoaphidis i C. obscurus.

4. Stwierdzono, że osobniki mszycy różano-trawowej w wyniku bezpośredniego kontaktu z podłożem glebowym pobranym wiosną spod żywicieli pierwotnych, ulegały infekcjom spowodowanym przez dwa gatunki grzybów, tj. C. obscurus i P. neoaphidis, co wskazuje na to, że gleba może być jednym ze źródeł materiału infekcyjnego tych gatunków w okresie wczesnowiosennym.

\section{Podziękowanie / Acknowledgements}

Wyniki badań zrealizowane w ramach tematu badawczego nr 245/08/S oraz częściowo 360/13/S, zostały sfinansowane z dotacji na naukę, przyznanej przez Ministerstwo Nauki i Szkolnictwa Wyższego.

\section{Literatura / References}

Bałazy S. 1993. Flora of Poland, Fungi (Mycota), Entomophthorales. Institute of Botany, Kraków, 356 ss.

Bałazy S., Miętkiewski R., Majchrowicz I. 1990. Mikozy mszyc - ich znaczenie i perspektywy wykorzystania w ochronie roślin. Zeszyty Problemowe Postępów Nauk Rolniczych 392: 35-56.

Barta M. 2009. Entomophthoralean fungi associated with aphids in woody plants in the Arboretum Mlyňany SAS. Folia Oecologica 36 (1): $1-7$.

Barta M., Cagáň L. 2002. Prevalence of natural fungal mortality of black bean aphid, Aphis fabae Scopoli on primary host and two secondary hosts. Acta Fytotechnica et Zootechnica 5 (3): 57-64.

Barta M., Cagaň L. 2006. Observations on the occurrence of Entomophthorales infecting aphids (Aphidoidea) in Slovakia. BioControl 51 (6): 795-808. DOI: 10.1007/s10526-006-9007-7.

Barta M., Stalmachová-Eliasová M., Hozzank A., Cagáň L., Wegensteiner R. 2003. Results of preliminary investigations on the occurrence of Entomophthorales on aphids in Austria. IOBC/WPRS Bulletin 26 (1): 81-83.

Baverstock J., Alderson P.G., Pell J.K. 2005. Pandora neoaphidis transmission and aphid foraging behaviour. Journal of Invertebrate Pathology 90 (1): 73-76. DOI: 10.1016/j.jip.2005.05.009.

Ben Fekih I., Boukhris-Bouhachem S., Allagui M.B., Brun Jensen A., Eilenberg J. 2015. First survey on ecological host range of aphid pathogenic fungi (Phylum Entomophthoromycota) in Tunisia. Annales de la Société Entomologique de France 51 (2): 140-144. DOI: 10.1080/00379271.2015.1059997.

Bode V.E. 1980. Untersuchungen zum Auftreten der Haferblattlaus Ropalosiphum padi (L.) Homoptera: Aphididae) an ihrem Winterwirt Prunus padus L. Zeitschrift für Angewandte Entomology 89 (4): 363-377.

Burd J.D. 2002. Physiological modification of the host feeding site by cereal aphids (Homoptera: Aphididae). Journal of Economic Entomology 95 (2): 463-468. DOI: 10.1603/0022-0493-95.2.463.

Cagáń L., Barta M. 2001. Seasonal dynamics and entomophthoralean infection of the pea aphid, Acyrthosiphon pisum Harris. Plant Protection Science 37 (1): 17-24.

Chen Ch., Feng M. 2004. Observation on the initial inoculum source and dissemination of Entomophthorales-caused epizootics in populations of cereal aphids. Science in China Series C Life Sciences 47 (1): 38-43. DOI: 10.1360/02yc0261.

Chomnunti P., Hongsanan S., Aguirre-Hudson B., Tian Q., Peršoh D., Dhami M.K., Alias A.S., Xu J., Liu X., Stadler M., Hyde K.D. 2014. The sooty moulds. Fungal Diversity 66 (1): 1-36. DOI: 10.1007/s13225-014-0278-5.

Cichocka E. 1980. Mszyce roślin sadowniczych Polski. PWN, Warszawa, 119 ss.

Corremans-Pelseneer J., Villiers S., Matthys V. 1983. Entomophthorales found on wheat aphids, in soil, and air on the same field. Four years compared results. Mededelingen van de Faculteit Landbouwwetenchappen Rijksuniversiteit Gent 48: $207-224$.

Dąbrowski Z.T. 1988. Podstawy odporności roślin na szkodniki. Wydanie II. PWRiL, Warszawa: 76-78, 260 ss.

Dedryver C.A., Gelle A., Tanguy S. 1983. Evolution des populations de Ropalosiphum padi L. sur son hôte primaire, Prunus padus L. dans deux stations du nor dwt de l'ouest de la France. Agronomie EDP Sciences 3 (1): 1-8. DOI: hal-00884477.

Feng M.G., Johnson J.B., Kish L.P. 1990. Survey of entomopathogenic fungi naturally infecting cereal aphids (Homoptera: Aphididae) of irrigated grain crops southwestern Idaho. Environmental Entomology 19: 1535-1542.

Feng M.G., Nowierski R.M., Scharen A.L., Sands D.C. 1991. Entomopathogenic fungi (Zygomycotina: Entomophthorales) infecting cereal aphids (Homoptera: Aphididae) in Montana. Pan-Pacific Entomologist 7 (1): 55-64.

Gadalińska-Krzyżanowska A. 2011. Ocena rozwoju mszyc zbożowych na pierwotnych i wtórnych roślinach żywicielskich. Praca doktorska. Uniwersytet Przyrodniczo-Humanistyczny w Siedlcach, 161 ss.

Goszczyński W. 1993. Zoocydy w ochronie roślin. Wydawnictwo SGGW, Warszawa.

Hatting J.L., Humber R.A., Poprawski T.J., Miller R.M. 1999. A survey of fungal pathogens of aphids from South Africa, with special reference to cereal aphids. Biological Control 16 (1): 1-12. DOI: 10.1006/bcon.1999.0731.

Howard M.T., Dixon A.F.G. 1992. The effect of plant phenology on the induction of alatae and the development of populations of Metopolophium dirhodum (Walker), the rose-grain aphid, on winter wheat. Annals of Applied Biology 120 (2): 203-213. DOI: 10.1111/ j.1744-7348.1992.tb03418.x.

Humber R.A. 1989. Synopsis of a revised classification for Entomophthorales (Zygomycotina). Mycotaxon 34 (2): $441-460$.

Humber R.A. 2012. Entomophthoromycota: a new phylum and reclassification for entomophthoroid fungi. Mycotaxon 120: 477-492. DOI: 10.5248/120.477. 
Keller S. (ed.). 2007. Arthropod-pathogenic Entomophthorales: biology, ecology, identification. COST Action 842, Luxembourg, Office for Official Publications of the European Communities: 66-81, 157 pp. ISBN 978-92-898-0037-2.

Krzyżanowski R. 2017. Dynamics serious pest of Metopolophium dirhodum (Walk.) (Hemiptera: Aphididae) occurring on shrubs of Rosa rugosa Thunb. Herba Polonica 63 (2): 27-33. DOI: 10.1515/hepo-2017-000X.

Krzyżanowski R., Leszczyński B. 2009. Volatile compounds of bird cherry as modulators of host plant alternation by bird cherry-oat aphid. Acta Biochimica Polonica 56: 25.

Latteur G. 1977. Sur la possibilité d infectiondirected_Aphides par Entomophthora à partir de sols hérbergeant un inoculum naturel. Comptes Rendus Academic de Sciences, Paris 284 (D): 2253-2256.

Leather S.R. 1982. Preliminary studies on the effect of host age and aphid generation on the reproduction and survival of the bird cherryoat aphid, Rhopalosiphum padi (L.). Annales Agriculturae Fenniae 21: 13-19.

Leszczyński B. 1985. Changes in phenols content and metabolism in leaves of susceptible and resistant winter wheat cultivars infested by (Rhopalosiphum padi L.) (Homoptera: Aphididae). Zeitschrift für Angewandte Entomologie 100: 343-348.

Leszczyński B., Cone W.W., Wright L.C. 1986. Changes in the sugar metabolism of asparagus plants infested by asparagus aphid, Brachycorynella asparagi and green peach aphid Myzus persicae. Journal of Agricultural Entomology 3: 25-30.

Li Z.Z. 2000. Flora Fungorum Sinicorum, Vol. 13: Entomophthorales. Science Press, Beijing, 168 pp.

Lykouressis D. 1984. A comparative study of different aphid population parameters in assessing resistance in cereals. Zeitschrift für Angewandte Entomologie 97: 77-84.

Nielsen Ch., Hajek A.E., Humber R.A., Bresciani J., Eilenberg J. 2003. Soil as an environment for winter survival of aphid-pathogenic Entomophthorales. Biological Control 28 (1): 92-100. DOI: 10.1016/S1049-9644(03)00033-1.

Nielsen Ch., Eilenberg J., Dromph K. 2001. Entomophthorales on cereal aphids. Characterisation, growth, virulence, epizootiology and potential for microbial control. Pesticides Research 53: 1-70.

Nielsen Ch., Steenberg T. 2004. Entomophthoralean fungi infecting the bird cherry-oat aphid, Rhopalosiphum padi, feeding on its winter host bird cherry, Prunus padus. Journal of Invertebrate Pathology 87 (1): 70-73. DOI: 10.1016/j.jip.2004.05.003.

Remaudière G., Latgé J.P., Michel M.F. 1981. Écologie comparée des entomophthoracées pathogènes de puceronsen France Littorale et Continentale. Entomophaga 26: 157-178.

Ruszkowska M. 2002. Przekształcenia cyklicznej partenogenezy mszycy Rhopalosiphum padi (L.) - znaczenie zjawiska w adaptacji środowiskowej. Rozprawy Naukowe Instytutu Ochrony Roślin, Zeszyt 8: 6-7.

Smith C.M., Boyko E., Starkey S. 2005. Differential expression of genes in wheat, Triticum aestivum L. controlling resistance to the Russian wheat aphid, Diuraphis noxia (Mordvilko). IOBC/WPRS Bulletin 28 (10): 11-20.

Štalmachová M., Cagáň L. 2000. Entomophtorales as significant natural enemies of cereal aphids infecting maize in Slovakia. IOBC/ WPRS Bulletin 23 (2): 187-191.

Steenberg T., Eilenberg J. 1995. Natural occurrence of entomopathogenic fungi on aphids at an agricultural field site. Czech Mycology 48: 89-96.

Urbańska A., Niraz S. 1990. Anatomiczne i biochemiczne aspekty żerowania mszyc zbożowych. Zeszyty Problemowe Postępów Nauk Rolniczych 392: 201-213.

Wratten S.D., Lee G., Stevens D.J. 1979. Duration of cereal aphid populations and the effects on wheat yield and quality. Proceedings of the British Crop Protection Conference - Pest and Diseases: 1-8.

Wratten S.D., Readhead P.C. 1976. Effects of cereal aphids on the growth of wheat. Annals of Applied Biology 84: 437-440.

Zhou X., Carter N. 1992. Effect of temperature, feeding position and crop growth stage on population dynamics of the rose-grain aphid, Metopolophium dirhodum (Hemiptera: Aphididae). Annals of Applied Biology 121 (1): 27-37. DOI: 10.1111/j.1744-7348.1992. tb03984.x.

Zwiener C.M., Conley S.P., Bailey W.C., Sweets L.E. 2005. Influence of aphid species and barley yellow dwarf virus on soft red winter wheat yield. Journal of Economic Entomology 98 (6): 2013-2019. 